\title{
OBSERVATIONS ON THE FEDERAL ROLE IN REGIONAL PLANNING COUNCILS
}

\author{
Mavis Mann Reeves
}

University of Maryland

With the Federal encouragement and support of regional planning, have we set in motion a trend we cannot stop? It is true that, as of the moment, these regional agencies are concerned only with planning. Will the fact that they are in existence and available for the performance of other functions encourage the extension of their activities by Congressional authorization from above? Those familar with the development of boards of county commissioners in some states will recall that these bodies began as judicial organs which served as appellate courts for justice of the peace cases. Because they were in existence, administrative duties were handed them piecemeal until their administrative functions far exceeded their judicial ones, most of which were gradually lost to other agencies, and they became the general administrative boards for the counties.

If this kind of incremental acquisition of administrative responsibility takes place with the regional planning councils, what will be the result? Presumably another layer of government would be inserted between the cities and counties on the one hand and the state on the other. This level would be imposed by the Federal government and not by the states which have traditionally had the responsibility for setting out the general pattern of local government within their boundaries. What, then, would happen to the diversity which has been a vitalizing circumstance in Americanlife? And is an entire recasting of the state-local relationship in the making?

Should the Federal government impose regional government on a population demonstrably reluctant to move toward that end? In most places where the question of area-wide government has been placed on the ballot, the voters have rejected it. Furthermore, unless there is some restructuring, governments would be proliferating, a development which could aggravate rather than mitigate fragmentation. These changes will not necessarily occur; but we should be aware of the possibility that they can happen and consider whether or not they are desirable. The idea of haphazard alterations of governmental institutions and relationships negates the whole idea of planning and rational determination of our course of action.

Even if these regional planning councils remain strictly as planning agencies and do not develop administrative roles, other questions must be raised. One of the chief ones involves the matter of government responsiveness of citizen demands. In recent years, demands have intensified for a citizen voice in the determination of what kind of community will be built. Will the elevation of many planning decisions to a higher level dilute the opportunity for citizens to affect the governmental decision-making process? Will the dispersion of the planning function add to public confusion and make it more difficult to determine who the decision makers are? Of related interest are questions of the effects of regional planning on political parties which are not organized on a regional basis. Will it become more difficult for parties to act responsibly and to deliver on their promises to the electorate?

Those interested in the preservation of the federal system will be concerned with its further deterioration. As direct relations between the Fed- 
eral government and local units increase and as regional organizations proliferate, the position of the state in the federal system declines at a more rapid rate. What is being projected here as a possibility is the re-structuring of the federalsystem. The circumvention of the states may lead to their atrophy. Even if it is desirable to move to a unitary system of government, and I do not believe that it is, it should not be undertaken in the guise of promoting planning, but carefully and with an awareness of the probable consequences. Professor Glendening makes a valuable contribution in highlighting these trends and outlining their implications. It is necessary to know where we aregoing so that we can direct our course, rather than taking the path of least resistance and easy availability as does a meandering stream. 